CORRECTION

\title{
Correction to: Urban environmental quality and out-migration intentions
}

\author{
Jiří Balcar ${ }^{1}\left[\right.$ ] Jan Šulák ${ }^{1}[$
}

Published online: 15 June 2021

(c) Springer-Verlag GmbH Germany, part of Springer Nature 2021

\section{Correction to: The Annals of Regional Science (2021) 66:579-607 https://doi.org/10.1007/s00168-020-01030-1}

Jan Šulák is thankful for the support of the Czech Science Foundation (Grant No. 18-16111S).

Publisher's Note Springer Nature remains neutral with regard to jurisdictional claims in published maps and institutional affiliations.

The original article can be found online at https://doi.org/10.1007/s00168-020-01030-1.

\section{Jiří Balcar}

jiri.balcar@vsb.cz

1 Faculty of Economics, VSB - Technical University of Ostrava, Sokolská třída 33, 70200 Ostrava, Czech Republic 